\title{
PERSPEKTIF BANTUAN HUKUM DI KOTA BOGOR DIHUBUNGKAN DENGAN UNDANG-UNDANG NOMOR 16 TAHUN 2011 TENTANG BANTUAN HUKUM
}

\section{PERSPECTIVE OF LEGAL ASSISTANCE IN BOGOR CITY ASSOCIATED WITH LAW NUMBER 16 YEAR 2011 CONCERNING LEGAL ASSISTANCE}

\author{
Roni Ismail, Endeh Suhartini
}

Program Studi Hukum, Sekolah Pascasarjana, Universitas Djuanda Bogor.

Korespondensi : Roni Ismail, Telp. 085222208664

e-mail : roni.ismail@gmail.com
Jurnal Living Law, Vol. 12, No. 1 , 2020

hlm. 74-86

\begin{abstract}
Legal aid is a constitutional right for Indonesian citizens to obtain legal protection and equality. The existence of Law Number 16 of 2011 is a manifestation of that constitutional right. Fulfillment of legal aid for the poor in Bogor City has been partially implemented using APBD funds in accordance with Regional Regulation No. 3 of 2015 concerning Legal Aid for the Poor and Mayor Regulation Number 39 of 2015 as the Implementing Regulation. The provision of legal aid to the poor in Bogor which refers to the Bogor City Regulation No. 3 of 2015 concerning Legal Aid for the Poor has not yet been realized specifically for the people of Bogor City. This is due to obstacles from external and internal factors in its implementation, namely in the form of a Legal Assistance Organization which is only one accredited at the Ministry of Law and Human Rights and limited funds for absorption of legal aid implementation activities. Therefore, the Government needs to involve Legal Aids (LKBH-LKBH) in private university institutions in Bogor and its surroundings to be able to realize the plan for establishing Legal Consultation innovations (legal clinics) in 68 urban office Bogor City
\end{abstract}

Keywords : Law; Legal Aid; Poor Society.

\begin{abstract}
Abstrak : Bantuan hukum merupakan hak konstitusional bagi warga negara Indonesia untuk mendapatkan perlindungan dan kesetaraan hukum. Adanya Undang-Undang Nomor 16 tahun 2011 merupakan wujud dari hak konstitusional tersebut. Pemenuhan bantuan hukum bagi masyarakat miskin di Kota Bogor sebagian telah dilaksanakan menggunakan dana APBD sesuai dengan Perda Nomor 3 Tahun 2015 tentang Bantuan Hukum Bagi Masyarakat Miskin dan Peraturan walikota Nomor 39 Tahun 2015 sebagai Peraturan Pelaksananya. Pemberian bantuan hukum pada masyarakat miskin di Kota Bogor yang mengacu pada Perda Kota Bogor Nomor 3 Tahun 2015 tentang Bantuan Hukum Bagi Masyarakat Miskin belum secara nyata terealisasikan khususnya bagi masyarakat Kota Bogor sendiri. Hal tersebut karena adanya hambatan dari faktor eksternal dan internal dalam pelaksanaannya, yaitu berupa Organisasi Bantuan Hukum (OBH) yang baru satu terakreditasi di Kemenkumham dan keterbatasan dana untuk penyerapan kegiatan penyelenggaraan bantuan hukum. Karena itu, Pemkot Bogor perlu melibatkan LKBH-LKBH yang ada pada perguruan tinggi swasta di Bogor dan sekitarnya untuk dapat mewujudkan rencana pembentukan inovasi Konsultasi Hukum (klinik hukum) di 68 Kelurahan.
\end{abstract}

Kata Kunci : Bantuan Hukum; Hukum Masyarakat; Miskin.

\section{PENDAHULUAN}

Bantuan hukum merupakan hak konstitusional bagi setiap warga negara atas jaminan perlindungan hukum dan jaminan persamaan di hadapan hukum karena sarana pengakuan HAM. Mendapatkan bantuan hukum bagi setiap orang adalah perwujudan access to justice 
(akses terhadap keadilan) yang merupakan implementasi dari jaminan perlindungan hukum. ${ }^{1}$ Hal ini sesuai dengan konsep bantuan hukum yang dihubungkan dengan cita-cita negara kesejahteraan (welfare state).2

Istilah bantuan hukum sendiri dipergunakan sebagai terjemahan dari dua istilah yang berbeda yaitu Legal Aid dan Legal Assistance. Istilah Legal Aid biasanya digunakan untuk pengertian bantuan hukum dalam arti sempit berupa pemberian jasa-jasa di bidang hukum kepada seseorang dalam suatu perkara secara cuma-Cuma (pro bono), ${ }^{3}$ khususnya bagi mereka yang tidak mampu. Sedangkan Legal Assistance dipergunakan untuk menunjukan pengertian bantuan hukum kepada mereka yang tidak mampu maupun pemberian bantuan hukum oleh para advokat yang menggunakan honorium. ${ }^{4}$

Di Indonesia, bantuan hukum berkembang pada hakikatnya tidak luput dari perkembangan bantuan hukum yang terdapat pada negara-negara yang telah maju. Pengertian bantuan hukum mempunyai ciri dan istilah yang berbeda. Menurut Adnan Buyung Nasution, ${ }^{5}$ bantuan hukum adalah: Legal Aid, yang berarti pemberian jasa di bidang hukum kepada seseorang yang terlibat dalam suatu kasus atau perkara:

1. Pemberian jasa bantuan hukum dilakukan dengan cuma-cuma.

2. Bantuan jasa hukum dalam legal aid lebih dikhususkan bagi yang tidak

\footnotetext{
${ }^{1}$ Lihat Penjelasan Umum Undang-Undang Nomor 16 Tahun 2011 tentang Bantuan Hukum.

2 Abdurrahman, Aspek-Aspek Bantuan Hukum di Indonesia, Penerbit Cendana Press, Jakarta, 1983, Hlm. 2.

3 Pro bono adalah kependekan dari frasa Latin pro bono publico, yang berarti "untuk kebaikan publik." Sumber: $\quad$ https://en.wikipedia.org >wiki>pro bono, diakses pada tanggal 20 Oktober 2019, jam. 20.15 WIB.

${ }^{4}$ Ibid., Hlm. 17-18.

${ }^{5}$ Adnan Buyung Nasution, dkk., Bantuan Hukum Akses Masyarakat Marginal Terhadap Keadilan (Tinjauan, Sejarah, Konsep, Kebijakan, Penerapan dan Perbandingan), LBH Jakarta, 2007, Hlm. 13.
}

mampu dalam lapisan masyarakat miskin.

3. Dengan demikian motivasi utama konsep legal aid adalah menegakkan hukum dengan jalan membela kepentingan hak azasi rakyat kecil yang tidak punya dan buta hukum.

Permasalahan untuk mendapatkan keadilan meskipun terbatas pada bantuan hukum, sebenarnya adalah masalah yang tidak mudah diuraikan. Hal ini karena masalah akses mendapatkan keadilan bukan hanya masalah hukum semata, melainkan juga masalah politik, bahkan lebih jauh lagi adalah masalah budaya. Persoalannya bertambah rumit apabila di lihat dari sudut ekonomi, yang disebabkan oleh kemiskinan yang semakin meluas, tingkat buta huruf yang tinggi dan keadaan kesehatan yang memburuk. ${ }^{6}$

Begitu lemah dan kurang adanya rasa keadilan dan hati nurani dari hukum positif yang lahir dari kebijakan hukum akibat dari proses politik yang tidak memberi kemanfaatan dan kepastian. Menurut Radbruck dalam Muhammad Taufiq, ${ }^{7}$ bahwa tujuan hukum secara bersama-sama, yaitu keadilan. Dengan demikian, keadilan haruslah dapat memberi kemanfaatan bagi masyarakat luas, terutama bagi rakyat miskin.

Diberlakukannya Peraturan Daerah Kota Bogor Nomor 3 Tahun 2015 tentang Bantuan Hukum Bagi Masyarakat Miskin, menambah daftar peraturan perundangundangan yang mengatur tentang bantuan hukum yang bersifat lex specialis. ${ }^{8}$ Bagi

\footnotetext{
${ }^{6}$ Ibid., Hlm. 3.

Muhammad Taufiq, Keadilan Substansial Memangkas Rantai Birokrasi Hukum, Cetakan I, Pustaka Pelajar, Yogyakarta, 2014, Hlm. 2.

${ }^{8}$ Lex specialis, dalam teori dan praktik hukum, adalah doktrin yang berkaitan dengan interpretasi hukum dan dapat diterapkan dalam konteks hukum domestik dan internasional. Doktrin menyatakan bahwa jika dua undang-undang mengatur situasi faktual yang sama, undang-undang yang mengatur materi pelajaran tertentu (lex specialis) menimpa undang-undang yang mengatur hanya masalah umum (lex generalis). Situasi ini biasanya muncul sehubungan dengan pembangunan legislasi khusus yang diberlakukan sebelumnya ketika legislasi yang lebih umum kemudian disahkan. Namun,
} 
masyarakat yang tidak mampu (miskin) di Kota Bogor dikeluarkannya Peraturan Daerah Kota Bogor Nomor 3 Tahun 2015 tentang Bantuan Hukum Bagi Masyarakat Miskin merupakan suatu inovasi dalam pelaksanaan dari Undang-Undang Nomor 16 Tahun 2011 tentang Bantuan Hukum.

Bantuan hukum kepada masyarakat miskin atau tidak mampu berdasarkan Undang-Undang Nomor 16 Tahun 2011, diberikan oleh Pemberi Bantuan Hukum. Pemberi Bantuan Hukum adalah Lembaga Bantuan Hukum (LBH) atau Organisasi Kemasyarakatan. Hal ini dapat di lihat dalam Pasal 1 angka (3), yang menyebutkan: "Pemberi Bantuan Hukum adalah lembaga bantuan hukum atau organisasi kemasyarakatan yang memberi layanan bantuan hukum berdasarkan Undang-undang ini".

Tidak semua LBH atau Organisasi Kemasyarakatan dalam Undang-Undang Nomor 16 Tahun 2011 dapat menjadi Pemberi Bantuan Hukum, karena pada ketentuan Pasal 8 ayat (1) dan ayat (2), disebutkan:

(1) Pelaksanaan bantuan hukum dilakukan oleh Pemberi Bantuan Hukum yang telah memenuhi syarat berdasarkan Undang-undang;

(2) Syarat-syarat Pemberi Bantuan Hukum sebagaimana dimaksud pada ayat (1), meliputi:

(a) Berbadan hukum;

(b) Terakreditasi berdasarkan Undang-undang;

(c) Memiliki kantor atau sekretariat yang tetap;

(d) Memiliki pengurus; dan

kemudian, doktrin yang disebut "lex posterior derogat legi priori" juga berlaku, hukum yang lebih muda mengesampingkan hukum yang lebih tua. Istilah ini berasal dari pernyataan lengkap doktrin, pepatah hukum dalam bahasa Latin: Lex specialis derogat legi generali. Sumber: https://en.wikipedia.org>wiki>lex_specialis_derogat_le gi_generali, diakses pada tanggal 20 Oktober 2019, jam. 20.25. WIB. (e) Memiliki program bantuan hukum.

Provinsi Jawa Barat berdasarkan hasil verifikasi/akreditasi OBH oleh Kementerian Hukum dan HAM, berdasarkan Keputusan Menteri Hukum dan HAM Nomor: M.HH-01.HN.03.03 Tahun 2016 tentang Lembaga/Organisasi bantuan Hukum Yang Lulus Verifikasi Dan Akreditasi Sebagai Pemberi Bantuan Hukum Periode Tahun 2016 S.D. 2018, berjumlah 34 OBH terbagi dalam 3 (tiga) kategori, yaitu A, B, dan C, namun disayangkan untuk Kota Bogor sendiri belum ada $\mathrm{OBH}$ yang lolos verifikasi dan akreditasi.

Sejak dikeluarkannya Peraturan Daerah Kota Bogor Nomor 3 Tahun 2015, yang diundangkan pada tanggal 26 Oktober 2015, banyak problematika yang dialami oleh Pemerintah Daerah Kota Bogor dalam menjalankan Peraturan Daerah tersebut, terutama jika dihubungkan dengan Undang-Undang Nomor 16 Tahun 2011 tentang Bantuan Hukum, apakah dapat terlaksana secara efektif bagi orang yang tidak mampu untuk membayar atau memperoleh pembelaan.

Dengan latar belakang permasalahan yang telah diuraikan di atas, maka penelitian ini akan membahas lebih lanjut tentang implikasi pemberian bantuan hukum yang dilihat dari peraturan perundang-undangan yang diberlakukan, para Pemberi Bantuan Hukum, sampai pada faktor-faktor yang mempengaruhinya terhadap pelaksanaan pemberian bantuan hukum tersebut, sehingga peneliti tertarik untuk mengkaji dan menganalisis atas latar belakang penelitian ini untuk menjadi sebuah karya tulis ilmiah (tesis) dengan judul: "PERSPEKTIF BANTUAN HUKUM DI KOTA BOGOR DIHUBUNGKAN DENGAN UNDANG-UNDANG NOMOR 16 TAHUN 2011".

Berdasarkan latar belakang yang telah diuraikan sebelumnya di atas, maka dapat diidentifikasi permasalahan dalam penelitian ini adalah sebagai berikut: 
1. Bagaimanakah pemberian bantuan hukum pada masyarakat miskin di Kota Bogor berdasarkan pada Peraturan Daerah Kota Bogor Nomor 3 Tahun 2015, yang dihubungkan dengan Undang-Undang Nomor 16 Tahun 2011?

2. Apa saja faktor-faktor penghambat dalam pelaksanaan pemberian bantuan hukum pada masyarakat miskin di Kota Bogor berdasarkan pada Peraturan Daerah Kota Bogor Nomor 3 Tahun 2015, yang dihubungkan dengan Undang-Undang Nomor 16 Tahun 2011?

\section{METODE PENELITIAN}

Dalam melakukan penelitian ini, peneliti menggunakan cara pendekatan yuridis normatif, yaitu dengan meneliti pada data bahan hukum berupa UndangUndang Dasar 1945; Undang-Undang Nomor 16 Tahun 2011 tentang Bantuan Hukum; dan Peraturan Daerah Kota Bogor Nomor 3 Tahun 2015 tentng bantuan Hukum Bagi Masyarakat Miskin.

Untuk dapat lebih mendalami atas hasil penelitian ini, peneliti juga akan melakukan pendekatan secara yuridis empiris agar lebih diketahui implikasi peraturan perundang-undanganan tentang bantuan hukum bagi masyarakat miskin di Kota Bogor. Sehingga Penelitian ini dapat memberikan argumentasi hukum sebagai dasar penentu apakah suatu peristiwa sudah benar atau salah serta bagaimana seharusnya peristiwa itu menurut hukum yang berlaku. ${ }^{9}$

\section{PEMBAHASAN}

\section{A. PERATURAN DAERAH KOTA BOGOR NOMOR 3 TAHUN 2015 TENTANG BANTUAN HUKUM BAGI MASYARAKAT MISKIN.}

\footnotetext{
${ }^{9}$ Mukti Fajar N.D., dan Yulianti Achmad, Dualisme Penelitian Hukum Normatif dan Empiris, Pustaka Pelajar, Yogyakarta, 2010, Hlm. 36.
}

\section{Pengaturan Bantuan Hukum di Kota Bogor}

Penyelenggaraan pemberian bantuan hukum kepada warga Kota Bogor, khususnya bagi masyarakat miskin merupakan upaya untuk memenuhi dan sekaligus sebagai implementasi negara hukum yang mengakui dan melindungi serta menjamin hak asasi warga negara akan kebutuhan akses terhadap keadilan (access to justice) dan kesamaan di hadapan hukum (equality before the law). ${ }^{10}$

Jaminan atas hak konstitusional tersebut, oleh Pemerintah Daerah Kota Bogor telah mendapatkan perhatian secara memadai, yaitu dengan dibentuknya Peraturan Daerah Kota Bogor Nomor 3 Tahun 2015 tentang Bantuan Hukum bagi Masyarakat Miskin, sebagaimana diamanatkan dalam Pasal 19 ayat (2) Undang-Undang Nomor 16 Tahun 2011 tentang Bantuan Hukum menjadi dasar bagi Pemerintah Daerah untuk menjamin warga negara khususnya bagi orang atau kelompok orang miskin untuk mendapatkan akses keadilan dan kesamaan dihadapan hukum, oleh karena itu tanggung jawab Pemerintah Daerah harus diimplementasikan melalui pembentukan Peraturan Daerah.

Pengaturan mengenai pemberian bantuan hukum dalam Peraturan Daerah ini, kemudian ditindaklanjuti dengan Peraturan Walikota Bogor Nomor 39 Tahun 2015 tentang Peraturan Pelaksana Peraturan Daerah Kota Bogor Nomor 3 Tahun 2015 tentang Bantuan Hukum Bagi Masyarakat Miskin

\footnotetext{
10 Lihat Penjelasan Umum Peraturan Daerah Kota Bogor Nomor 3 Tahun 2015 tentang Bantuan Hukum Bagi Masyarakat Miskin.
} 
2. Tata Cara Permohonan Bantuan Hukum.

Permohonan bantuan hukum diajukan secara tertulis oleh pemohon bantuan hukum kepada Pemberi Bantuan Hukum dengan mengisi formulir. ${ }^{11}$ Dalam hal Pemohon Bantuan Hukum yang mengajukan permohonan tidak mempunyai kemampuan untuk mengajukan permohonan secara tertulis, permohonan dapat diajukan secara lisan dan langsung kepada Pemberi Bantuan Hukum serta harus dicatat oleh Pemberi Bantuan Hukum yang bersangkutan.

Permohonan Bantuan Hukum harus melampirkan:

a. Fotokopi Kartu Tanda Penduduk atau dokumen lain yang dikeluarkan oleh instansi yang berwenang;

b. Surat keterangan miskin dari lurah atau pejabat yang setingkat sesuai dengan domisili Pemohon Bantuan Hukum;

c. Dokumen yang berkenaan dengan perkara; dan

d. Surat kuasa, jika permohonan diajukan oleh keluarga atau kuasanya.

\section{Pelaksanaan Pemberian Bantuan Hukum.}

Pemberian Bantuan Hukum hanya dapat dilakukan oleh Pemberi Bantuan Hukum yang telah diakreditasi oleh Menteri Hukum dan HAM sesuai dengan ketentuan peraturan perundang-undangan. Pemberian Bantuan Hukum dilaksanakan oleh Pemberi Bantuan Hukum setelah bekerjasama dengan Pemerintah Daerah yang dituangkan dalam Perjanjian Kerja Sama pelaksanaan Bantuan Hukum. ${ }^{12}$

\footnotetext{
${ }^{11}$ Lihat Lampiran Perwali Nomor 39 Tahun 2015.

12 Lihat Lampiran. (Sumber: Bagian Hukum Dan Hak Asasi Manusia, Pemerintah Daerah Kota Bogor).
}

Untuk Anggaran Bantuan Hukum Pemberi Bantuan Hukum mengajukan rencana anggarannya secara tertulis kepada Walikota melalui Bagian Hukum dan Hak Asasi Manusia Sekretariat Daerah Kota Bogor. Pengajuan rencana Anggaran Bantuan Hukum dilaksanakan sesuai dengan perjanjian kerja sama pelaksanaan Bantuan Hukum yang telah ditandatangani. ${ }^{13}$

Pemberi Bantuan Hukum melaksanakan Bantuan Hukum Litigasi dan Nonlitigasi sesuai dengan ketentuan yang diatur dalam perjanjian pelaksanaan bantuan hukum dan ketentuan peraturan perundang-undangan. Dan untuk mengajukan permohonan pencairan anggaran ditujukan kepada Kepala Bagian Hukum dan HAM Pemerintah Daerah Kota Bogor, disertai dengan laporan penyelesaian perkara dan bukti pendukung.

\section{B. PELAKSANAAN BANTUAN HUKUM BAGI MASYARAKAT MISKIN DI KOTA BOGOR.}

\section{Pelaksanaan Bantuan Hukum Oleh Pemerintah Daerah Kota Bogor}

Kegiatan atas bantuan hukum untuk masyarakat miskin oleh Bagian Hukum dan Hak Asasi Manusia (HAM) Pemerintah Daeerah Kota Bogor sebagaimana diamanatkan Peraturan Walikota Bogor Nomor 39 Tahun 2015 tentang Peraturan Pelaksana Peraturan Daerah Kota Bogor Nomor 3 Tahun 2015 tentang Bantuan Hukum Bagi Masyarakat Miskin, untuk tahun anggaran (TA) 2018 diselanggarakan oleh 3 (tiga) Lembaga Bantuan Hukum yang berasal dari luar Kota Bogor dan terakreditai oleh Kementerian Hukum dan HAM, yaitu Lembaga Bantuan Hukum Masyarakat Cibinong Bogor,

\footnotetext{
${ }^{13}$ Lihat Lampiran.
} 
Yayasan Bantuan Hukum Amalbi Depok, dan Yayasan Bantuan Hukum Kusuma Bangsa Cianjur.

Baru pada Tahun 2019 berdasarakan lampiran Keputusan Menteri Hukum dan Hak Asasi Manusia (Menkumham) Republik Indonesia Nomor: M.HH-01.HH.07.02 Tahun 2018 tentang Lembaga/Organisasi Bantuan Hukum Yang Lulus Verifikasi Dan Akreditasi Sebagai Pemberi Bantuan Hukum Periode Tahun 2019 S.D. 2021, Pemerintah Kota Bogor bekerjasama dengan satu-satunya untuk wilayah Kota Bogor OBH yang terdaftar dan terakreditasi, yaitu Lembaga Bantuan Hukum Sinar Asih, yang berlamat dan berkantor di Jalan Dalurung Raya Nomor 17, Kecamatan Bogor Utara, Kota Bogor, Jawa Barat ${ }^{14}$ bersamasama dengan Lembaga Bantuan Hukum Masyarakat Cibinong Bogor dan Yayasan Bantuan Hukum Amalbi Depok.

\section{Hambatan Dalam Pelaksanaan Bantuan Hukum Di Kota Bogor.}

Dalam pelaksanaan kegiatan pemberian bantuan hukum bagi masyarakat miskin di Wilayah Hukum Kota Bogor, menurut Plt. Kepala Bagian Hukum dan HAM, Sekretariat Pemerintah Daerah Kota Bogor Amik Herwidyastuti, ${ }^{15}$ hambatan dalam implementasi Peraturan Daerah (Perda) terkait dengan keberaaan OBH yang terakreditasi masih di luar

\footnotetext{
${ }^{14}$ Lihat Lampiran Keputusan Menteri Hukum dan Hak Asasi Manusia (HAM) Republik Indonesia Nomor: M.HH-01.HH.07.02 Tahun 2018 tentang Lembaga/Organisasi Bantuan Hukum Yang Lulus Verifikasi Dan Akreditasi Sebagai Pemberi Bantuan Hukum Periode Tahun 2019 S.D. 2021, pada halaman poin 183.

${ }^{15}$ Wawancara dengan Ibu Amik Herwidyastuti, S.H., M.H., Plt. Kepala Bagian Hukum dan HAM, Sekretariat Pemerintah Daerah Kota Bogor, di Kantor Bagian Hukum Pemerintah Daerah Kota Bogor, Jalan Ir. H. Juanda No. 10, Kota Bogor, tanggal 29 Agustus 2019, jam. 10.15 WIB.
}

Kota Bogor, sehingga masyarakat yang membutuhkan bantuan harus ketempat $\mathrm{OBH}$ atau janjian di Pengadilan Negeri atau di kantor Pemerintah Daerah Kota Bogor. Untuk mengatasi hal tersebut, Pemerintah Daerah Kota Bogor meminta kepada Kemenkumham RI untuk menyelenggarakan akreditasi sendiri bagi $\mathrm{OBH}$, namun tidak diijinkan karena kewenangan akreditasi berdasarkan UndangUndang Nomor 16 Tahun 2011 tentang Bantuan Hukum ada di Menkumham.

Pada akhirnya, untuk mengatasi hal tersebut di atas, Pemerintah Kota Bogor bekerja sama dengan LBH di Cianjur, Depok dan Cibinong dengan mengharuskan OBH tersebut menunjuk Pembela Umum (Advokat) yang ada di Kota Bogor untuk mempermudah masyarakat mengajukan permohonan bantuan hukum.

Selain itu, menurut Amik Herwidyastuti, ${ }^{16}$ masih banyak masyarakat miskin Kota Bogor yang belum sepenuhnya mendapatkan bantuan hukum karena keterbatasan anggaran. Namun LBH diarahkan tetap melayani bantuan hukum secara cuma-cuma (prodeo) atau menggunakan anggaran provinsi atau nasional.

\section{ANALISIS YURIDIS TERHADAP BANTUAN HUKUM UNTUK MASYARAKAT MISKIN MENURUT PERATURAN DAERAH KOTA BOGOR $\begin{array}{llll}\text { NOMOR } & 3 & \text { TAHUN } & 2015\end{array}$ DIHUBUNGAKAN DENGAN UNDANG- UNDANG NOMOR 16 TAHUN 2011 TENTANG BANTUAN HUKUM}

Adanya Undang-Undang Nomor 16 Tahun 2011 tentang Bantuan Hukum (selanjutnya disebut dengan Undang-

\footnotetext{
${ }^{16}$ Ibid.
} 
Undang Bantuan Hukum) menimbulkan konsekuensi pembebanan kewajiban kepada Pemerintah untuk mengalokasikan dana penyelenggaraan bantuan hukum dalam APBN. Pendanaan penyelenggaraan bantuan hukum dialokasikan pada anggaran kementerian yang menyelenggarakan urusan pemerintahan di bidang hukum dan hak asasi manusia dalam hal ini Kementerian Hukum dan HAM RI. Namun Pembentuk UndangUndang Bantuan Hukum menyadari bahwa dana yang dialokasikan dalam APBN tidak akan mampu untuk memenuhi semua permohonan bantuan hukum yang ada di seluruh daerah. Untuk itu Undang-Undang Bantuan Hukum melalui ketentuan Pasal 19 memberi ruang bagi daerah untuk mengalokasikan dana penyelenggaraan bantuan hukum dalam APBD.

Undang-Undang Bantuan Hukum memang tidak membebankan kewajiban bagi daerah untuk mengalokasikan dana penyelenggaraan bantuan hukum. Karena dalam ketentuan Pasal 19 ayat (1) menggunakan frasa 'dapat', sehingga tersedia pilihan bagi daerah apakah akan mengaturnya atau tidak. Akan tetapi apabila daerah berkehendak mengalokasikan dana penyelenggaraan bantuan hukum dalam APBD, maka Pemerintah Daerah dan DPR Daerah harus mengaturnya dalam Peraturan Daerah. ${ }^{17}$

Pemerintah Daerah Kota Bogor, dalam memberikan jaminan bagi warga negara khususnya bagi orang atau kelompok orang miskin untuk mendapatkan akses keadilan dan kesamaan di hadapan hukum, sebagaimana diamanatkan dalam Pasal 19 ayat (2) Undang-Undang Bantuan Hukum tersebut sebagai tanggung jawab Pemerintah Daerah harus diimplementasikan melalui pembentukan

\footnotetext{
${ }^{17}$ Bachtiar, Urgensi Penyelenggaraan Bantuan Hukum Bagi Masyarakat Miskin Oleh Pemerintah Daerah, SALAM: Jurnal Sosial \& Budaya Syar-i, FSH UIN Syarif Hidayatullah, Jakarta, Vol. 3 No. 2, 2016, hlm. 139.
}

Peraturan Daerah, ${ }^{18}$ yaitu dengan hadirnya Peraturan Daerah Kota Bogor Nomor 3 Tahun 2015 tentang Bantuan Hukum Bagi Masyarakat Miskin, yang ditetapkan dan diundangkan pada tanggal 26 Oktober 2015.

Mengingat pentingnya bantuan hukum dalam menciptakan keadilan, menegakkan HAM dan equality before the law, serta dalam mencapai due process of law, tentu menjadikan kewajiban pemberian bantuan hukum menjadi hal yang penting untuk dapat dilaksanakan secara efektif, ${ }^{19}$ maka sebagaimana ketentuan Pasal 5, Pasal 24 ayat (2) dan Pasal 26 Peraturan Daerah Kota Bogor Nomor 3 Tahun 2015 tentang Bantuan Hukum Bagi Masyarakat Miskin, perlu menetapkan Peraturan Walikota Bogor tentang Peraturan Pelaksanaan Peraturan Daerah Kota Bogor Nomor 3 Tahun 2015 tentang Bantuan Hukum Bagi Masyarakat Miskin. ${ }^{20}$

Organisasi Bantuan Hukum (OBH) yang seharusnya mendukung bagi terlaksananya bantuan hukum bagi masyarakat miskin Kota Bogor, belum memadai. $\mathrm{OBH}$ yang terdaftar dan terakreditasi untuk wilayah hukum di Kota Bogor hanya baru LEMBAGA BANTUAN HUKUM SINAR ASIH saja. ${ }^{21}$ Berarti menjadi persoalan dalam penerapan pemberian bantuan hukum bagi masyarakat miskin Kota Bogor. Meskipun secara regulasi telah mumpuni untuk itu.

Agar dapat terlaksananya bantuan hukum bagi masyarakat miskin di Kota

\footnotetext{
18 Lihat Penjelasan Umum Peraturan Daerah Kota Bogor Nomor 3 Tahun 2015 tentang Bantuan Hukum Bagi Masyarakat Miskin.

19 Yustinus Dedi, Implementasi Pemberian Bantuan Hukum Kepada Masyarakat Miskin Dalam Rangka Mencari Keadilan Berdasarkan Undang-Undang Nomo 16 tahun 2011 Tentang Bantuan Hukum (Studi Di Kabupaten Bengkayang), Jurnal Nestor Magister Hukum, Vol.2 No. 2 (2016), Hlm. 7-8.

20 Lihat Pertimbangan Peraturan Walikota Bogor tentang Peraturan Pelaksanaan Peraturan Daerah Kota Bogor Nomor 3 Tahun 2015 tentang Bantuan Hukum Bagi Masyarakat Miskin.

${ }^{21}$ Lihat Lampiran Keputusan Menteri Hukum dan Hak Asasi Manusia (HAM) Republik Indonesia Nomor: M.HH-01.HH.07.02 Tahun 2018.
} 
Bogor, maka menurut penulis, Pemerintah Daerah Kota Bogor dapat melakukan kerja sama dengan cabang organisasi profesi Advokat yang ada di Kota Bogor sebelum adanya $\mathrm{OBH}$ terbentuk dan terakreditasi lainnya. Mengingat masih terdaftar dan terakreditasinya oleh Kemenkumham hanya satu-satunya OBH yang ada di Kota Bogor. ${ }^{22}$ Sesuai dengan ketentuan Pasal 1 angka 8 Perda Nomor 3 Tahun 2015 tentang Bantuan Hukum Bagi Masyarakat Miskin, menyebutkan bahwa Pemberi Bantuan Hukum adalah Lembaga Bantuan Hukum atau organisasi kemasyarakatan yang memberi layanan bantuan hukum sesuai dengan ketentuan peraturan perundang-undangan. Pada ketentuan Pasal 10 ayat (1), disebutkan bahwa Pemberian Bantuan Hukum secara litigasi dilakukan oleh Advokat yang berstatus sebagai pengurus Pemberi Bantuan Hukum dan/atau Advokat yang direkrut oleh Pemberi Bantuan Hukum.

Pemerintah Daerah Kota Bogor mengimplementasikan dengan Peraturan Daerah Kota Bogor Nomor 3 Tahun 2015 tentang Bantuan Hukum Bagi Masyarakat Miskin dan Peraturan Walikota Bogor tentang Peraturan Pelaksanaan Peraturan Daerah Kota Bogor Nomor 3 Tahun 2015 tentang Bantuan Hukum Bagi Masyarakat Miskin.

Pemberian bantuan hukum yang dilakukan oleh Advokat belum banyak menyentuh orang atau kelompok orang yang tidak mampu secara ekonomi, sehingga kelompok tersebut kesulitan untuk mengakses keadilan karena terhambat oleh ketidakmampuannya untuk mewujudkan hak-hak konstitusionalnya. Keberpihakan pemerintah daerah terhadap masyarakatnya yang bermasalah dengan hukum melalui upaya pemberian bantuan hukum yang sudah menjadi inisiatif dari Pemerintah Daerah Kota Bogor, sekiranya dapat memanfaatkan Organisasi Profesi Advokat yang ada di Kota Bogor.

\footnotetext{
${ }^{22}$ Lihat Lampiran Keputusan Menteri Hukum dan Hak Asasi Manusia (HAM) Republik Indonesia Nomor: M.HH-01.HH.07.02 Tahun 2018.
}

Dalam konteks tersebut di atas, maka masyarakat kecil dan miskin begitu sulit mendapatkan keadilan tanpa adanya campur tangan dan bantuan dari negara. Perbedaan sosial dan permasalahan pada struktur sosial masyarakat tak akan dapat diselesaikan tanpa adanya campur tangan negara. Hadirnya negara terkait adanya kesenjangan sosial di masyarakat bertujuan membuka kesempatan kepada kelompok masyarakat rentan untuk mendapatkan keadilan. Usaha dan campur tangan negara untuk menciptakan kesejahteraan tidak terpusat pada bidang ekonomi semata, namun juga dalam bidang hukum seperti pemberian bantuan hukum bagi masyarakat miskin. Bantuan hukum dimasukkan sebagai salah satu program peningkatan kesejahteraan rakyat. ${ }^{23}$

\section{FAKTOR-FAKTOR PENGHAMBAT PELAKSANAAN PEMBERIAN BANTUAN HUKUM PADA MASYARAKAT MISKIN DI KOTA BOGOR.}

Dalam pelaksanaan bantuan hukum bagi masyarakat miskin di Kota Bogor, Pemerintah Daerah Kota Bogor masih memiliki hambatan atau kekurangan. Hambatan atau kekurangan yang dihadapi, yaitu:

1. Faktor Eksternal.

Masih kurangnya OBH yang terkakreditasi oleh Kemenkumham, sehingga sulit untuk dilaksanakannya program bantuan hukum bagi masyarakat miskin di Kota Bogor. ${ }^{24}$ Sedangkan apabila ditinjau dari ketentuan Pasal 8 ayat 2 UndangUndang Bantuan Hukum, maka OBH harus telah memenuhi semua

\footnotetext{
${ }^{23}$ Bachtiar, Op.Cit., Hlm. 142.

${ }^{24}$ Wawancara dengan Ibu Amik Herwidyastuti, S.H., M.H., Plt. Kepala Bagian Hukum dan HAM, Sekretariat Pemerintah Daerah Kota Bogor, di Kantor Bagian Hukum Pemerintah Daerah Kota Bogor, Jalan Ir. H. Juanda No. 10, Kota Bogor, tanggal 29 Agustus 2019, jam. 10.15 WIB.
} 
persyaratan lain untuk bertindak sebagai pemberi bantuan hukum. ${ }^{25}$

Sejak diverifikasi dan diakreditasi oleh Kementerian Hukum dan HAM pada 31 Mei 2013, hanya ada satu OBH di Kota Bogor, yaitu LEMBAGA BANTUAN HUKUM SINAR ASIH. Namun dalam pelaksanaannya, Pemerintah Daerah Kota Bogor dalam menyerap anggaran untuk bantuan hukum, memakai OBH sebagai pihak Pemberi Bantuan Hukum di luar wilayah Kota Bogor, yaitu: Yayasan LBH Kusuma Bangsa Cianjur dan LBH Masyarkat Cibinong. ${ }^{26}$

2. Faktor Internal.

Adapun hambatan lain yang dihadapi oleh Pemerintah Daerah Kota Bogor dalam pelaksanaan kegiatan bantuan hukum bagi masyarakat miskin, terkendala oleh faktor internal sendiri, yaitu keterbatasan anggaran sehingga agar tetap dapat melayani bantuan hukum secara cuma-cuma (prodeo) kepada masyarakat miskin di Kota Bogor, dapat menggunakan anggaran provinsi atau nasional. ${ }^{27}$ Namun anggaran/dana untuk bantuan hukum bagi masyarakat miskin yang diberikan belum secara merata, akibat birokrasi yang sangat lamban. ${ }^{28}$

Adapun faktor lain yang menyebabkan kurangnya pelaksanaan bantuan hukum bagi masyarakat miskin, khususnya di Kota Bogor, menurut penulis karena ketidak tahuan masyarakat yang terkena kasus pidana pada umumnya masih rendah. Kelompok tersebut tidak mengetahui bahwa sebagai masyarakat miskin atau tidak mampu yang sedang menghadapi masalah hukum berhak untuk mendapat

\footnotetext{
${ }^{25}$ Pasal 7 ayat (1) Undang-Undang Nomor 16 Tahun 2011 tentang Bantuan Hukum.

${ }^{26}$ Lihat Tabel.

27 Wawancara dengan Ibu Amik Herwidyastuti, S.H., M.H., Plt. Kepala Bagian Hukum dan HAM, Sekretariat Pemerintah Daerah Kota Bogor.

28 Mosgan Situmorang, Penelitian Hukum Tentang Tanggung Jawab Negara dan Advokat Dalam Memberikan Bantuan Hukum Kepada Masyarakat, Badan Pembinaan Hukum Nasional (BPHN), Kementerian Hukum dan HAM RI, 2011, Hlm. 53.
}

bantuan hukum. Pada umumnya apabila ditawarkan apakah akan didampingi Advokat atau tidak dan mereka mengatakan tidak karena tidak mampu untuk membayar. ${ }^{29}$

Kurangnya pengetahuan masyarakat tentang bantuan hukum sebagai hakhaknya yang harus di penuhi dan juga kurangnya pemberitahuan atau sosialisasi dari pejabat yang berwenang, dalam hal ini Pemerintah Daerah Kota Bogor dalam rangka agar kelompok masyarakat miskin atau tidak mampu mengetahui hak-haknya. Terkadang pada proses pemberian bantuan hukum sebagai hak dari tersangka atau terdakwa seakan dihalang-halangi. Dengan adanya bantuan hukum terhadap tersangka atau terdakwa harus dilakukan oleh Pemerintah sedini mungkin hal ini untuk mencegah agar tidak ada lagi dirampas hak-haknya oleh para aparatur penegak hukum misalnya banyak kasus yang sering dijumpai, banyak tersangka yang telah ditahan melebihi masa pidana yang semestinya dijalani, kekerasan sering muncul dalam setiap pemeriksaan. ${ }^{30}$

Faktor eksternal dan internal tersebut di atas yang dihadapi oleh Pemerintah Daerah Kota Bogor dalam hambatan pelaksanaan bantuan hukum bagi masyarakat miskin, apabila dihubungkan dengan Undang-Undang Bantuan Hukum maka Pemerintah Daerah merupakan institusi penting dalam pelaksanaan kehidupan bernegara. Sesuai peraturan perundang-undangan Indonesia, Pemerintah Daerah merupakan pelaksana asas desentralisasi di mana pemerintah pusat menyerahkan sebagian urusannya kepada daerah untuk dikelola secara mandiri. Dalam konteks ini Pemerintah Daerah diberi kebebasan untuk mengatur dirinya sendiri dalam rangka pelaksanaan otonomi daerah, antara lain melalui penerbitan produk hukum daerah. Melalui kewenangan yang dimilikinya, pada dasarnya Pemerintah Daerah mempunyai peluang untuk mengimplementasikan

\footnotetext{
${ }^{29}$ Ibid., Hlm. 55.

${ }^{30}$ Bachtiar, Op.Cit., Hlm. 159.
} 
kegiatan bantuan hukum, terutama bagi masyarakat tidak mampu. ${ }^{31}$

Keberadaan Perda Kota Bogor Nomor 3 Tahun 2015 tentang Bantuan Hukum Bagi Masyarakat Miskin merupakan suatu hal yang krusila untuk diwujudkan sebagai bentuk komitmen dan political will setiap Pemerintah Daerah terhadap masyarakat tidak mampu di daerahnya. Begitu pula Peraturan Walikota Bogor Nomor 39 Tahun 2015 tentang Peraturan Pelaksana Perdan Nomor 3 Tahun 2015, pada dasarnya merupakan peraturan yang ditujukan untuk menjamin adanya pelayanan publik yang disediakan Pemerintah Daerah (Pemda) Kota Bogor kepada masyarakatnya.

Dengan Perda dan Perwali itu merupakan penegasan dari Pemda Kota Bogor sebagai akses dan kewajibannya dalam pelayanan publik terhadap warganya. Melalui regulasi-regulasi itu, diatur prinsip-prinsip jaminan dan perlindungan hak atas bantuan hukum yang menjadi bagian dari pelayanan publik bagi warga masyarakat di daerah Kota Bogor. Oleh karena itu, keberadaan Perda tentang Penyelenggaraan Bantuan Hukum bagi masayarakat miskin sangat penting untuk diadakan tidak hanya dalam rangka menjamin hak atas bantuan hukum dalam rangka untuk meningkatkan pelayanan publik, tetapi juga menjamin hak-hak konstitusional warga masyarakat demi mencapai tujuan rakyat daerah yang sejahtera. $^{32}$

\section{E. UPAYA PEMERINTAH DAERAH KOTA BOGOR DALAM MENYELESAIKAN PERSOALAN YANG TIMBUL DARI PELAKSANAAN BANTUAN HUKUM BAGI MASYARAKAT MISKIN.}

Pemkot Bogor telah melakukan suatu inovasi dalam pemberian bantuan hukum bagi masyarakat miskin pada tahun 2020 mendatang akan disiapkan layanan Lembaga Bantuan Hukum (LBH) di 68

\footnotetext{
${ }^{31}$ Ibid., Hlm. 149.

${ }^{32}$ Ibid., Hlm. 150.
}

(enam puluh delapan) Kelurahan yang ada di Kota Bogor, terutama dalam menyiapkan ruangan untuk konsultasi hukum yang diperkirakan akan rampung pada 2020. Untuk pengajuan bantuan hukum, masyarakat cukup mengadukan ajuan hukum ke bagian hukum atau langsung ke LBH. Nanti LBH akan mengkomunikasikannya ke Bagian Hukum dan HAM. 33

Selain itu, dalam menjamin hak atas bantuan hukum bagi masyarakat miskin sebagai wujud pengabdian kepada masyarakat, ${ }^{34}$ maka peranan LKBH Kampus memiliki posisi strategis dalam pemberian bantuan hukum. Hal ini dapat dilihat dari tiga hal, yaitu: Pertama, jumlah dan sebaran LKBH Kampus merata, bahkan di daerah yang terpencil sekalipun. Fakultas Hukum yang mendirikan LKBH menjadi peluang bagi pencari keadilan untuk mendapatkan bantuan hukum; Kedua, di dukung oleh sumber daya manusia yang jumlahnya cukup, baik tenaga pengajar maupun mahasiswa. Pengetahuan hukum menjadi

33

https://kotabogor.go.id/index.php/show_post/detail/131 19/tahun-depan-pemkot-bogor-siapkan-bantuanhukum-di-68-kelurahan, diakses pada tanggal 10 September 2019, jam 22.54. WIB.

34 Strategi pengembangan pendidikan hukum yang men-dukung implementasi bantuan hukum sebagaimana dicanangkan oleh Bapenas, merujuk pada konsep Pendidikan Hukum Klinis (Clinical Legal Education/CLE). CLE sendiri merupakan salah satu cara bagaimana keadilan sosial secara efektif dapat diaplikasikan ke dalam pendidikan tinggi hukum. CLE merupakan learning pro-cess dimana mahasiswa fakultas hukum diberikan pengetahuan praktis (practical knowledge), keahlian (skill) dan nilai-nilai (value)untuk memberikan pelayanan kepada masyarakat berdasarkan pada nilai-nilai keadilan sosial. Metode pengajaran dilakukan secara interaktif dan reflektif. Komponen penunjang CLE, diantaranya adalah legal clinic atau sering disebut Lembaga Konsultasi dan Bantuan Hukum (LKBH/LBH Kampus). Sumber: Tim The Indonesian Legal Resource Center dan Forum Solidaritas LKBH Kampus, Menjamin hak Atas Bantuan Hukum Bagi Masyarakat Marginal, Position Paper RUU Bantuan Hukum dan Peran LKBH Kampus, ILRC, Jakarta, 2012, Hlm. 4., diakses dari http://mitrahukum.org/wpcontent/uploads/2012/09/Position-Paper-RUU-BH.pdf, pada tanggal 10 September 2019, jam. 21.10. WIB. 
modal yang baik untuk memberikan layanan bantuan hukum. Ketiga, orientasi non profit. LKBH merupakan bagian pelaksanaan Tridharma Perguruan Tinggi, yaitu dharma ketiga pengabdian kepada masyarakat. 35

Alasan pemberian bantuan hukum dengan melibatkan LKBH Kampus, karena orientasi landasan yang kokoh untuk memberikan layanan hukum yang tidak beror-entasi pada keuntungan. Idealisme pengajar dan mahasiswa Fakultas Hukum dapat tersalurkan, dan pencari keadilan terpenuhi hak-haknya. Sebelum diberlakukannya Undang-Undang Advokat, LKBH Kampus menjadi salah satu penyedia bantuan hukum bagi masyarakat miskin/marginal. Disamping melaksanakan peran pengabdian terhadap masyarakat dan pendidikan bagi mahasiswa, peran tersebut diambil untuk menjawab ketidaktersediaan Advokat. Setelah pemberlakuan Undang-Undang Advokat, hal itu sudah tidak dapat dilakukan lagi. ${ }^{36}$

Oleh karena itu, Pemkot Bogor, menurut penulis dalam rangka pemenuhan bantuan hukum bagi masyarakat miskin yang akan dicanangkan pada tahun 2020 nanti tersebut dapat mengikutsertakan LKBH-LKBH yang ada di beberapa perguruan tinggi swasta yang ada di Kota Bogor dan sekitarnya. Hal ini sejalan dengan jaminan perlindungan negara terhadap pelaksanaan hak-hak dasar masyarakat. Jaminan perlindungan tersebut diarahkan kepada adanya akses keadilan bagi para pencari keadilan, khususnya bagi masyarakat yang tidak mampu, melalui suatu instrumen hukum yang membuka ruang bagi masyarakat untuk memperoleh hak-hak konstitusionalnya, yaitu hak atas bantuan hukum.

Sesuai dengan ketentuan Pasal 13 Perda Nomor 3 Tahun 2015 tentang Bantuan Hukum Bagi Masyarakat Miskin, bahwa bentuk pemberian bantuan hukum

\footnotetext{
35 Tim The Indonesian Legal Resource Center, Ibid., Hlm. 5.

${ }^{36}$ Ibid.
}

dapat melakukan pelayanan dengan menyelenggarakan penyuluhan hukum, konsultasi hukum, dan program kegiatan lain yang berkaitan dengan penyelenggaraan bantuan hukum.

\section{KESIMPULAN}

Dari hasil pembahasan yang telah dilakukan oleh penulis tersebut di atas, maka dapat disimpulkan bahwa:

1. Dalam pemberian bantuan hukum pada masyarakat miskin di Kota Bogor yang mengacu pada Perda Kota Bogor Nomor 3 Tahun 2015 tentang Bantuan Hukum Bagi Masyarakat Miskin belum secara nyata terealisasikan khususnya bagi masyarakat Kota Bogor sendiri. Hal ini karena hanya satu LBH yang terakreditasi oleh Kemenkumham sebagai Organisasi Bantuan Hukum $(\mathrm{OBH})$ yang berhak untuk dapat menjadi Pemberi Bantuan Hukum sesuai peraturan perundang-undangan. Selain itu pula, peran Advokat di Kota Bogor sebagai profesi pemberi jasa hukum belum banyak terlibat dalam pelaksanaan bantuan hukum bagi masyarakat miskin.

2. Kendala OBH yang belum terakreditasi dan pendanaan untuk sektor pelayanan bantuan hukum bagi masyarakat miskin merupakan hambatan sebagai faktor eksternal dan internal bagi Pemerintah Kota (Pemkot) Bogor dalam pelaksanaan kegiatan bantuan hukum bagi masyarakat miskin. Perlunya peranan pusat, provinsi dan organisasi profesi hukum (PERADI) Kota Bogor, agar tanggung jawab terhadap kewajiban-kewajiban negara dalam hal ini Pemkot Bogor untuk menjamin dan melindungi hak-hak konstitusional warga negaranya.

3. Pemkot Bogor dalam menyelesaikan persoalan yang timbul dari pelaksanaan bantuan hukum bagi masyarakat miskin mencanangkan bentuk konsultasi hukum di 68 (enam puluh delapan) Kelurahan dengan ruangan khusus untuk dapat 
memberikan pelayanan hukum berupa penyelenggaraan konsultasi hukum bagi masyarakat Kota Bogor. Dalam rangka tersebut, Pemkot Bogor akan bekerja sama dengan LKBH-LKBH yang ada di perguruan tinggi swasta yang ada di Kota Bogor sekitarnya. Adapun pendanaannya dibebankan kepada APBD Kota Bogor sesuai dengan ketentuan Perda Nomor 3 Tahun 2015 dan Perwali Nomor 39 Tahun 2015 tentang Peraturan Pelaksanaan bantuan Hukum Bagi Masyarakat Miskin.

\section{SARAN}

Berdasarkan kesimpulan tersebut di atas, penulis ingin mengemukakan beberapa saran yang diperlukan, dengan harapan dapat menjadi bahan masukan, yaitu sebagai berikut:

1. Perlunya Pemkot Bogor sebagai fasilitator untuk membantu berdirinya $\mathrm{OBH}-\mathrm{OBH}$ di Kota Bogor yang belum terakreditasi oleh Kemenkumham. Peran Bagian Hukum dan HAM, Sekretariat Pemerintah Daerah Kota Bogor sebagai bidang yang melaksanakan Perda tentang Bantuan Hukum untuk lebih progresif pada pembentukan OBH-OBH yang ada.

2. Pemkot Bogor sekiranya dapat mengupayakan dari perusahaanperusahaan yang ada di wilayah Kota Bogor sebagai bentuk Coporate Social Responsibity (CSR) perusahaan yang bersangkutan dalam menggalang bantuan dana Pemberian Bantuan Hukum, selain dari alokasi APBD yang ada.

3. Kerjasama Pemkot Bogor dengan pihak kampus swasta di Kota Bogor dan sekitarnya, untuk dapat menggerakan suatu penyelenggaraan pelayanan dan konsultasi hukum bagi masyarakat miskin sebagai wujud dari salah satu bentuk Tri-Dharma Perguruan Tinggi, yaitu Pengabdian pada masyarakat.

\section{DAFTAR PUSTAKA}

Abdurrahman, Aspek-Aspek Bantuan Hukum di Indonesia, Penerbit Cendana Press, Jakarta, 1983.

Adnan Buyung Nasution, dkk., Bantuan Hukum Akses Masyarakat Marginal Terhadap Keadilan (Tinjauan, Sejarah, Konsep, Kebijakan, Penerapan dan Perbandingan), LBH Jakarta, 2007.

Bachtiar, Urgensi Penyelenggaraan Bantuan Hukum Bagi Masyarakat Miskin Oleh Pemerintah Daerah, SALAM: Jurnal Sosial \& Budaya Syar-i, FSH UIN Syarif Hidayatullah, Jakarta, Vol. 3 No. 2, 2016.

Muhammad Taufiq, Keadilan Substansial Memangkas Rantai Birokrasi Hukum, Cetakan I, Pustaka Pelajar, Yogyakarta, 2014.

Mukti Fajar N.D., dan Yulianti Achmad, Dualisme Penelitian Hukum Normatif dan Empiris, Pustaka Pelajar, Yogyakarta, 2010.

Mosgan Situmorang, Penelitian Hukum Tentang Tanggung Jawab Negara dan Advokat Dalam Memberikan Bantuan Hukum Kepada Masyarakat, Badan Pembinaan Hukum Nasional (BPHN), Kementerian Hukum dan HAM RI, 2011.

Yustinus Dedi, Implementasi Pemberian Bantuan Hukum Kepada Masyarakat Miskin Dalam Rangka Mencari Keadilan Berdasarkan Undang-Undang Nomo 16 tahun 2011 
Tentang Bantuan Hukum (Studi Di Kabupaten Bengkayang), Jurnal Nestor Magister Hukum, Vol.2 No. 2 (2016)

Sumber: https://en.wikipedia.org>wiki >lex specialis_derogat_legi_generali, diakses pada tanggal 20 Oktober 2019, jam. 20.25. WIB. 